\title{
Kinerja Individu Sebagai Pengukuran Kesuksesan Adopsi SIA dengan Model UTAUT dan Delone \& Mc Lean
}

\author{
Gede Surya Pratama1 \\ Dodik Ariyanto ${ }^{2}$ \\ Ayu Aryista Dewi ${ }^{3}$ \\ ${ }^{1,2,3}$ Fakultas Ekonomi dan Bisnis Universitas Udayana (Unud), Bali, Indonesia \\ e-mail:gedepratama57@yahoo.com
}

\begin{abstract}
ABSTRAK
Tujuan penelitian adalahmengetahui pengaruh ekspektasi kinerja (performance expectancy), ekspektasi usaha (effort expectancy), faktor sosial (social influence) dan kondisi yang memfasilitasi (facilitating conditions) serta kualitas sistem dan kualitas informasi terhadap persepsi kinerja individu pada sistem informasi akuntansi Bank Perkreditan Rakyat di Kota Denpasar. Populasi penelitian adalah individu yang menggunakan sistem informasi akuntansi dalam menjalankan pekerjaannya. Pengambilan sampel penelitian menggunakan teknikpurposive sampling, dimana prosespengambilan sampel yang di dasari pada kriteriakriteria tertentu. Sehingga jumlah sampel yang digunakan dalam penelitian adalah sebanyak 13 BPR dengan jumlah responden sebanyak 100 karyawan BPR. Pengumpulan data menggunakan kuisioner dan teknik analisis data yang digunakan adalah analisis regresi linier berganda. Hasil analisis dalam penelitian menunjukkan bahwa : ekspektasi kinerja (performance expectancy), ekspektasi usaha (effort expectancy), faktor sosial (social influence), kondisi yang memfasilitasi (facilitating conditions), kualitas sistem dan kualitas informasi berpengaruh positif dan signifikan terhadap kinerja individu.
\end{abstract}

Kata Kunci: UTAUT, De Lone and Mc Lean, kinerja individu.

\begin{abstract}
The research objective was to determine the effect of performance expectations, effort expectations, social influence and facilitation conditions as well as system quality and information quality on perceptions of individual performance in the Rural Bank accounting information system in Denpasar. The research population is individuals who use accounting information systems in carrying out their work. The research sample was taken using a purposive sampling technique, where the sampling process was based on certain criteria. So that the number of samples used in this study were $13 \mathrm{BPR}$ with a total of $100 \mathrm{BPR}$ employees. Data collection using questionnaires and data analysis techniques used are multiple linear regression analysis. The results of the analysis in the study showed that: performance expectations (performance expectations), business expectations (business expectations), social factors (social influences), facilitation conditions (facilitation conditions), system quality and information quality had a positive and significant effect on individual performance.
\end{abstract}

Keywords: UTAUT, De Lone and Mc Lean, individual performance. 


\section{PENDAHULUAN}

Teknologi informasi membuat informasi dibutuhkan oleh berbagai sektor kegiatan bisnis menjadi lebih cepat, tepat waktu, relevan, dan akurat. Kegiatan bisnis berlomba merancang suatu TI yang baik, handal, berkualitas, dan mudah digunakan. Perkembangan terhadap teknologi informasi diiringi pula dengan perkembangan sistem informasi berbasis teknologi yang mengalami kemajuan dan perkembangan yang sangat pesat. Hal tersebut memberikan pengaruh yang signifikan terhadap penerapan sistem informasi akuntansi di dalam suatu organisasi, sehingga kebutuhan akan informasi yang tepat, handal dan akurat dalam kondisi lingkungan yang penuh dengan ketidak pastian mutlak diperlukan.

Teknologi informasi yang canggih harus didukung oleh aplikasi pendukung teknologi moderen, yang nantinya diharapkan dapat memberikan dampak positif bagi kelangsungan kinerja perusahaan dengan menghasilkan laporan keuangan yang tepat waktu, akurat, dan dapat dipercaya (Radityo dan Zulaikha, 2007). Sistem informasi akuntansi dalam suatu perusahaan menjadi sarana penting untuk meningkatkan efisiensi perusahaan dan mendukung daya saing perusahaan dengan menyediakan informasi akuntansi dan keuangan bagi manajemen. Kemudahan suatu sistem dan pemanfaatan dalam pengelolaan sistem tersebut oleh pemakai sistem merupakan penentu dari keberhasilan suatu sistem yang dimiliki suatu perusahaan (ALsarayreh et al, 2011). Semakin luas dan kompleknya aktivitas perekonomian akan mendorong setiap perusahaan untuk mampu mengelola aktivitas perekonomiannya dengan baik. Teknologi informasi memainkan peran kunci dalam bisnis modern terutama dalam kaitannya dengan fungsi akuntansi 
(Jap et a,l 2006). Dengan demikian, untuk meningkatkan kinerja organisasi dan khususnya meningkat kinerja individu karyawan agar dapat meningkatkan efisiensi perusahaan dan mendukung daya saing perusahaan, maka sangat diperlukan teknologi informasi yang canggih (terkomputerisasi dan terintegrasi) yang mudah digunakan oleh karyawan.

Model pemanfaatan dan penggunaan teknologi informasi telah banyak dikembangkan oleh para peneliti. Salah satunya adalah penelitian mengenai Unified Theory of Acceptance and Use of Technology (UTAUT) yang dikembangkan oleh (Davis dan Venkatesh, 1996). Pada model ini, terdapat empat variabel yang memiliki peranan penting sebagai faktor yang memiliki pengaruh yang signifikan terhadap persepsi kinerja individu dalam menggunakan teknologi informasi, empat variabel tersebut yaitu: performance expectancy, effort expectancy, social influence, dan facilitating conditions. Hasil penelitian terdahulu yang dilakukan oleh Bendi dan Sri Andayani (2013), Jati (2012), Sedana dan Wijaya (2012), Pertiwi dan Ariyanto (2017) mendapatkan hasil bahwa ekspektasi kinerja dan ekspektasi usaha berpengaruh positif terhadap peningkatan kinerja karyawan.

Hasil berbeda ditemukan oleh Meiranto (2018) yang menyatakan bahwa terdapat hubungan positif tapi tidak signifikan menggunakan sistem informasi dan membutuhkan biaya sehingga kinerja individu dalam menggunakan sistem informasi cenderung menurun. Dengan demikian dapat disimpulkan bahwa apabila seorang individu meyakini bahwa dengan menggunakan sistem teknologi informasi akan membantu dalam meningkatkan kinerjanya (memiliki ekspektasi 
kinerja yang tinggi), dan terdapat kemudahan pemakaian penggunaan teknologi informasi (Ekspektasi usaha) tersebut, maka individu tersebut akan termotivasi untuk meningkatkan kinerjanya dengan memanfaatkan sistem teknologi informasi yang tersedia di perusahaan.

Temuan penelitian oleh Pertiwi dan Ariyanto (2017) ,mendapatkan hasil bahwa faktor sosial dan kondisi yang memfasilitas berpengaruh positif terhadap kinerja individu dalam menggunakan sistem teknologi informasi. Hasil berbeda ditemukan oleh Bekti (2014), Rahmawati (2008) yang menyatakan bahwa faktor sosial tidak mempunyai pengaruh positif terhadap kinerja individu.Kemudian penelitian Krismadinata et al, (2018) menemukan hasil bahwa kondisi fasilitas tidak berpengaruh signifikan pada kinerja individu. Hal ini disebabkan oleh karena responden merasa bahwa kondisi fasilitas saat ini belum cukup memadai, tidak memiliki ruang khusus untuk entri data dan akses ke pusat pengolahan data lambat serta sering terjadi error sistem, sehingga tidak mampu meningkatkan kinerja individu. Sedangkan penelitian serupa oleh Wicaksono et al, (2017) memperoleh hasil penelitian yaitu persepsi kenyamanan, pengaruh sosial, dan kondisi yang memfasilitasi berpengaruh positif dan signifikan terhadap penggunaan TI. Lebih lanjut, persepsi kenyaman, kondisi yang memfasilitasi, dan penggunaan TI berpengaruh positif signifikan terhadap kinerja individu. Dengan demikian dapat disimpulkan apabila individu mendapat dukungan dari rekan kerja maupun atasannya bahwa dia harus menggunakan sistem baru dalam pekerjaannya dan juga didukung oleh tersedianya fasilitas penggunaan teknologi informasi dari organisasi, maka individu tersebut akan termotivasi untuk 
meningkatkan kinerjanya dengan memanfaatkan sistem teknologi informasi yang tersedia di perusahaan.

Selain model UTAUT yang dikembangkan olehDavis dan Venkatesh (1996), terdapat pula model yang dikembangkan oleh DeLone dan McLean (1992), terkait kesuksesan sistem informasi. melakukan penelitian yang mendalam terhadap literatur mengenai kesuksesan sistem informasi. Hasil penelitian menemukan bahwa kesuksesan sebuah sistem informasi dapat direpresentasikan oleh karakteristik kualitatif sistem informasi (system quality), kualitas output dari sistem informasi (information quality), konsumsi terhadap output (use), respon pengguna terhadap sistem informasi (user satisfaction), pengaruh sistem informasi terhadap kebiasaan pengguna (individual impact) dan pengaruh sistem informasi terhadap kinerja organisasi (organizational impact). Dalam penelitian ini akan menambahkan dua variabel dari model DeLone dan McLean (1992),yaitu variabel karakteristik kualitatif sistem informasi (system quality), kualitas output dari sistem informasi (information quality) yang nantinya akan memberikan pengaruh pada kinerja individu atau karyawan.

Penelitian yang dilakukan Jati dan Lakstio (2012),mendapatkan hasil yaitu kualitas sistem informasi, kualitas informasi, kualitas layanan, dan kondisi yang memfasilitasi dapat mempengaruhi kinerja individu pengguna sistem informasi melalui kepuasan penggunanya. Memperoleh hasil yang serupa yaitu kualitas informasi dan kualitas sistem informasi berpengaruh terhadap kepuasan pengguna dan kinerja pengguna sistem informasi. Hasil yang berbeda diperoleh Marlinawati (2013), mendapatkan hasil bahwa kualitas sistem informasi berpengaruh tidak 
signifikan terhadap kinerja, kemudian Risiyanto (2014), mendapatkan hasil yaitu kualitas informasi tidak berpengaruh signifikan terhadap kinerja individu dikarenakan banyak faktor yang mempengaruhi, seperti informasi yang dibutuhkan oleh karyawan bisa didapat dari luar accurate accounting system, dan pengguna accurate accounting system kurang mempercayai informasi yang didapatkan oleh accurate accounting system. Selanjutnya penelitianJati dan Lakstio (2012) ,membuktikan bahwa kualitas sistem informasi akuntansi berpengaruh positif signifikan pada kinerja individu pegawai. Dengan demikian dapat disimpulkan bahwa semakin baik kualitas sistem yang dimiliki dan semakin baik kualitas informasi yang tersedia pada perusahaan, maka kinerja individu akan semakin meningkat.

Penelitian ini akan memfokuskan pada Bank Perkreditan Rakyat (BPR). BPR merupakan lembaga keuangan mikro yang memiliki fungsi dan peran yang strategis dalam mendorong pertumbuhan usaha mikro, kecil dan menengah (UMKM) serta sekaligus sebagai badan keuangan yang dapat melakukan pemberdayaan bagi pengusaha lokal sebagai bentuk nyata dari kegiatan ekonomi yang berbasis kerakyatan. Kinerja Bank Perkreditan Rakyat (BPR) saat ini masih menghadapi beberapa permasalahan, baik dari sisi internal dan eksternal. Hal ini diungkapkan oleh Ketua Dewan Komisioner Otoritas Jasa Keuangan (OJK), Muliaman D Hadad dalam Seminar Kajian Pengembangan Produk dan Layanan Serta Strategi Branding Brand BPR di hotel Aryaduta, Jakarta, Senin, 10 Juli 2017 pada media infobanknews.com. 
Menurut Ketua Dewan Komisaris OJK masalah yang dihadapi BPR dari sisi eksternal adalah tantangan persaingan yang semakin meningkat. Saat ini segmen mikro dan kecil yang merupakan target pasar BPR juga dilayani oleh lembaga jasa keuangan lain selain bank seperti Lembaga Keuangan Mikro (LKM), Koperasi Simpan Pinjam, credit union, dan Fintech. Sehingga persaingan pada sektor mikro dan kecil menjadi sangat ketat. Berdasarkan permasalahan tersebut, maka OJK menerbitkan rangkaian ketentuan yang memperkuat pengaturan kelembagaan, prudential banking, teknologi informasi, manajemen risiko dan tata kelola (GCG), maupun kegiatan usaha yang sesuai dengan kapasitas permodalan BPR, serta kajian pengembangan produk dan layanan BPR yang mampu menjawab kebutuhan masyarakat yaitu produk dan layanan BPR berbasis jasa dan teknologi informasi.

Penggunaan sistem teknologi informasi akuntansi dapat membantu operasional BPR dalam menampung seluruh informasi yang dibutuhkan agar dapat membuat keputusan secara akurat. Namun fenomena yang terjadi dilapangan menunjukkan bahwa masih terdapat BPR yang tidak mampu menggunakan sistem informasi akuntansi dengan maksimal dalam kegiatan operasionalnya. Salah satu contoh kasus BPR di Bali yang tidak dapat menggunakan sistem informasi akuntansi dengan maksimal adalah BPR KS Bali Agung Sedana.

Otoritas Jasa Keuangan (OJK) mencabut izin usaha PT BPR KS Bali Agung Sedana yang berlokasi di Badung Bali. Pencabutan izin usaha ini tertuang dalam Keputusan Anggota Dewan Komisioner Nomor: KEP-202/D.03/2017 
tentang Pencabutan Izin Usaha PT BPR KS Bali Agung Sedana. OJK menyebutkan, penetapan status Bank Dalam Pengawasan Khusus disebabkan kesalahan pengelolaan oleh manajemen BPR, yang mengakibatkan kinerja keuangan BPR tidak dapat memenuhi standar yang ditetapkan sesuai ketentuan yang berlaku. Namun, upaya penyehatan yang dilakukan BPR sampai dengan batas waktu yang ditentukan, tidak dapat memperbaiki kondisi BPR untuk keluar dari status Bank Dalam Pengawasan Khusus yang harus memiliki Rasio Kewajiban Penyediaan Modal Minimum (CAR) paling kurang sebesar 4 persen.

Contoh kasus pada BPR KS Bali Agung Sedana tersebut seharusnya dapat dijadikan contoh bagi seluruh BPR di Bali khususnya di Denpasar, agar dapat menggunakan sistem informasi akuntansi yang tersedia dengan maksimal dan meningkatkan faktor-faktor yang dapat mempengaruhi kinerja pegawai BPR dalam menggunakan sistem informasi akuntansi dengan meningkatkan ekspektasi kinerja (performance expectancy), ekspektasi usaha (effort expectancy), faktor sosial (social influence), kondisi yang memfasilitasi (facilitating conditions), kualitas sistem dan kualitas informasi. Hasil penelitian Pertiwi dan Ariyanto (2017), menunjukkan bahwa model UTAUT bisa dipergunakan untuk mengukur perilaku penggunaan teknologi informasi, khususnya untuk meningkatkan kinerja individu dalam menggunakan sistem informasi akuntansi.

Berdasarkan fenomena hasil penelitian dan permasalahan pada BPR yang sudah dijelaskan sebelumnya, maka dalam penelitian ini bertujuan untuk mengetahui pengaruh ekspektasi kinerja (performance expectancy), ekspektasi usaha (effort expectancy), faktor sosial (social influence), kondisi yang 
memfasilitasi (facilitating conditions), kualitas sistem dan kualitas informasi terhadap persepsi kinerja individu pada sistem informasi akuntansi BPR di Kota Denpasar.

Berdasarkan penelusuran pada kajian pustaka dan hasil - hasil penelitian sebelumnya, maka model penelitian dapat digambarkan seperti pada Gambar 1 .

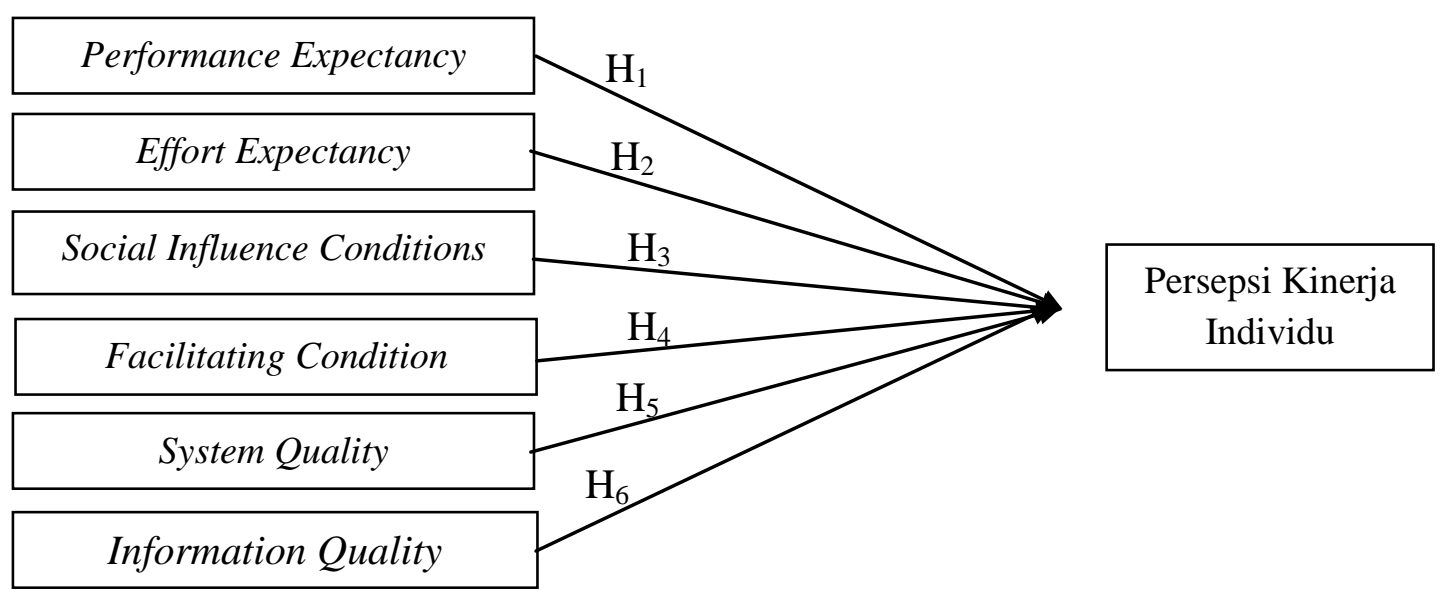

\section{Gambar 1. Model Penelitian}

Sumber : Data diolah, 2018

Berdasarkan pada latar belakang, tujuan penelitian dan hasil dari penelitian sebelumnya, maka hipotesis dalam penelitian ini adalah sebagai berikut:

$\mathrm{H}_{1}$ : Ekspektasi kinerja berpengaruh positif dan signifikan terhadap persepsi kinerja individu.

$\mathrm{H}_{2}$ : Ekspektasi usaha berpengaruh positif dan signifikan terhadap persepsi kinerja individu

$\mathrm{H}_{3}$ : Faktor sosial berpengaruh positif dan signifikan terhadap persepsi kinerja individu

$\mathrm{H}_{4}$ : Kondisi yang memfasilitasi berpengaruh positif dan signifikan terhadap persepsi kinerja individu 
$\mathrm{H}_{5}$ : Kualitas sistem berpengaruh positif dan signifikan terhadap persepsi kinerja individu

$\mathrm{H}_{6}$ : Kualitas informasi berpengaruh positif dan signifikan terhadap persepsi kinerja individu

\section{METODE PENELITIAN}

Penelitian dilakukan pada Bank Perkreditan Rakyat yang berlokasi di Kota Denpasar yang telah menerapkan sistem informasi akuntansi untuk mengolah data akuntansinya. Dipilihnya lokasi ini berdasarkan pertimbangan bahwa adanya perkembangan usaha berskala mikro, kecil dan menengah (UMKM) yang menggunakan Bank Perkreditan Rakyat sebagai tempat simpan pinjam.

Variabel terikat dalam penelitian adalah Persepsi Kinerja Individu (Y). Sedangkan, variabel bebas dalam penelitian ini adalah performance expectancy (harapan kinerja) $\left(\mathrm{X}_{1}\right)$, effort expectancy (harapan usaha) $\left(\mathrm{X}_{2}\right)$, social influence conditions (kondisi pengaruh sosial) $\left(\mathrm{X}_{3}\right)$, facilitating condition (kondisi yang memfasilitasi) $\left(\mathrm{X}_{4}\right)$, kualitas sistem $\left(\mathrm{X}_{5}\right)$, dan kualitas informasi $\left(\mathrm{X}_{6}\right)$. Seluruh variabel tersebut diukur menggunakan indikator yang dapat dilihat pada Tabel 1.

Populasi penelitian adalah individu yang menggunakan sistem informasi akuntansi dalam menjalankan pekerjaannya. Jumlah BPR di Kota Denpasar yang terdaftar pada Perbarindo DPK Denpasar tahun 2018 adalah sebanyak 13 unit, sehingga jumlah sampel yang digunakan dalam penelitian ini adalah sebanyak 114 responden. Responden dalam penelitian ini kemudian dipilih dengan kriteriakriteria bahwa responden merupakan karyawan BPR di Kota Denpasar yang sudah bekerja minimal selama 3 tahun dan menjalankan pekerjaannya dengan menggunakan sistem akuntansi. 
ISSN: 2302-8556

E-Jurnal Akuntansi

Vol.28.2.Agustus (2019): 1607-1632

Tabel 1.

Variabel dan Indikator Penelitian

\begin{tabular}{|c|c|c|}
\hline Variabel & Indikator & Referensi \\
\hline $\begin{array}{l}\text { Performance } \\
\text { Expectancy } \\
\quad(\mathrm{X} 1)\end{array}$ & $\begin{array}{l}\text { SIA bermanfaat untuk kegiatan akuntansi di BPR } \\
\text { Penggunaan SIA akan meningkatkan peluang saya untuk } \\
\text { mengembangkan kinerja } \\
\text { SIA akan meningkatkan mutu BPR } \\
\text { SIA memungkinkan untuk mempermudah proses kegiatan } \\
\text { akuntansi }\end{array}$ & $\begin{array}{c}\text { Venkatesh et } \\
\text { al. (2003) }\end{array}$ \\
\hline Effort & Saya merasa SIA mudah digunakan & \\
\hline $\begin{array}{l}\text { Expectancy } \\
(\mathrm{X} 2)\end{array}$ & $\begin{array}{l}\text { Penggunaan SIA cukup jelas dan mudah dipahami } \\
\text { Belajar untuk menggunakan SIA mudah bagi saya } \\
\text { SIA sesuai dengan teknologi informasi yang terbaru dan } \\
\text { banyak digunakan }\end{array}$ & $\begin{array}{c}\text { Venkatesh et } \\
\text { al. (2003) }\end{array}$ \\
\hline $\begin{array}{l}\text { Social } \\
\text { Influence } \\
\text { Conditions } \\
\quad \text { (X3) }\end{array}$ & $\begin{array}{l}\text { Lingkungan kantor berpendapat sebaiknya menggunakan SIA } \\
\text { BPR telah mendukung dalam penggunaan SIA } \\
\text { Kebijakan pimpinan BPR mengharuskan saya menggunakan } \\
\text { SIA } \\
\text { Manajemen BPR telah mendukung penggunaan SIA }\end{array}$ & $\begin{array}{c}\text { Venkatesh et } \\
\text { al. (2003) }\end{array}$ \\
\hline $\begin{array}{l}\text { Facilitation } \\
\text { Condition } \\
\quad(\mathrm{X} 4)\end{array}$ & $\begin{array}{l}\text { Saya memiliki pengetahuan yang cukup untuk menggunakan } \\
\text { SIA } \\
\text { Saya memiliki sumber daya yang dibutuhkan untuk } \\
\text { menggunakan SIA } \\
\text { Ada orang atau tim yang akan membantu saya jika menghadapi } \\
\text { kesulitan dalam penggunaan SIA } \\
\text { Peralatan di kantor (laptop, komp, dll) sudah mendukung } \\
\text { penggunaan SIA }\end{array}$ & $\begin{array}{c}\text { Venkatesh et } \\
\text { al. (2003) }\end{array}$ \\
\hline $\begin{array}{c}\text { Kualitas } \\
\text { Sistem (X5) }\end{array}$ & $\begin{array}{l}\text { SIA mampu meningkatkan kapasitas pemrosesan data. } \\
\text { SIA memiliki keamanan sistem. } \\
\text { Kesalahan yang terjadi mudah diidentifikasi dan dikoreksi. } \\
\text { SIA memuat informasi yang cukup untuk dapat membantu } \\
\text { memahami fungsi-fungsi yang ada dalam sistem tersebut. } \\
\text { SIA mudah dipelajari oleh penggunanya. }\end{array}$ & $\begin{array}{c}\text { Davis et al. } \\
\text { (1998). }\end{array}$ \\
\hline $\begin{array}{l}\text { Kualitas } \\
\text { Informasi } \\
\quad(\mathrm{X} 6)\end{array}$ & $\begin{array}{l}\text { Informasi yang dihasilkan oleh SIA tersebut akurat. } \\
\text { Informasi yang dihasilkan oleh SIA tersebut dapat dipercaya. } \\
\text { Informasi yang dihasilkan oleh SIA tersebut tepat waktu. } \\
\text { Informasi yang dihasilkan oleh SIA tersebut relevan. } \\
\text { Informasi yang dihasilkan oleh SIA tersebut mudah dipahami. } \\
\text { Informasi yang dihasilkan oleh SIA tersebut bersifat detail dan } \\
\text { benar. }\end{array}$ & $\begin{array}{l}\text { McGill et al. } \\
\text { (2003). }\end{array}$ \\
\hline $\begin{array}{c}\text { Kinerja } \\
\text { Individu (Y) }\end{array}$ & $\begin{array}{l}\text { SIA membantu menyelesaikan tugas dengan lebih cepat. } \\
\text { SIA yang digunakan mampu meningkatkan produktivitas kerja. } \\
\text { SIA yang digunakan mampu meningkatkan efektivitas dalam } \\
\text { melakukan pekerjaan sehari-hari. } \\
\text { Penggunaan SIA mempermudah penggunanya dalam } \\
\text { menyelesaikan pekerjaan. } \\
\text { SIA yang digunakan bermanfaat dalam pekerjaan. }\end{array}$ & $\begin{array}{l}\text { Davis etal. } \\
\text { (1998) }\end{array}$ \\
\hline
\end{tabular}

Sumber : Data diolah, 2019

Kriteria tersebut digunakan karena responden yang digunakan sebagai sampel penelitian sebaiknya menggunakan subjek profesional dalam menjalankan 
tugas-tugasnya. Hal ini sesuai dengan klasifikasi profesional menurut Chau dan $\mathrm{Hu}$ (2002), yaitu dilatih khusus pada bidang tertentu, berpraktik mandiri dan bekerja secara profesional dalam menjalankan pekerjaan-pekerjaannya. Berdasarkan hal tersebut, peneliti memilih yang tergolong profesional di lingkungan BPR yang terkait penggunaan sistem informasi akuntansi.

Metode pengumpulan data yang digunakan dalam penelitian ini adalah menggunakan wawancara dan kuesioner yang diukur dengan menggunakan skala likert 4 poin. Data instrumen penelitian yang sudah terkumpul dan sudah di rekapitulasi selanjutnya di uji validasi untuk mengukur sah atau valid tidaknya suatu kuesioner, dan untuk mengukur kehandalan jawaban responden menggunakan uji reliabilitas. Apabila data sudah dinyatakan layak dan sudah lolos uji validitas dan reliabiltas, maka selanjutnya dilakukan uji asumsi klasik karena model regresi yang baik adalah model regresi yang terbebas dari masalah normalitas data, multikolinieritas, dan heteroskedastisitas. Selanjutnya apabila data sudah dinyatakan lolos uji asumsi klasik, maka dilakukan uji hipotesis menggunakan analisis regresi linier berganda.

Analisis regresi linear berganda (multiple linear regression) digunakan untuk menguji hipotesis yang ada yaitu untuk melihat pengaruh variabel performance expectancy $\left(\mathrm{X}_{1}\right)$, effort expectancy $\left(\mathrm{X}_{2}\right)$, social influence conditions $\left(\mathrm{X}_{3}\right)$ dan facilitation condition $\left(\mathrm{X}_{4}\right)$, kemudian kualitas sistem $\left(\mathrm{X}_{5}\right)$,dankualitas informasi $\left(\mathrm{X}_{6}\right)$ terhadap persepsi kinerja individu pada sistem informasi akuntansi BPR di Kota Denpasar, maka ditentukanlah bentuk model persamaan analisis regresi linear berganda sebagai berikut. 


$$
Y=\alpha+\beta_{1} X_{1}+\beta_{2} X_{2}+\beta_{3} X_{3}+\beta_{4} X_{4}+\beta_{5} X_{5}+\beta_{6} X_{6}+\varepsilon_{1}
$$

Keterangan:

$$
\begin{aligned}
& Y=\text { persepsi kinerja individu } \\
& \alpha=\text { konstanta } \\
& \beta_{1} \ldots \beta_{6}=\text { koefisien regresi } \\
& X_{1}=\text { performance expectancy } \\
& X_{2}=\text { effort expectancy } \\
& X_{3}=\text { social influence conditions } \\
& X_{4}=\text { facilitation condition } \\
& X_{5}=\text { kualitas sistem } \\
& X_{6}=\text { kualitas informasi } \\
& \varepsilon_{1}=\text { variabel pengganggu }
\end{aligned}
$$

\section{HASIL DAN PEMBAHASAN}

Data penelitian diperoleh dari hasil kuesioner yang telah disebarkan kepada responden penelitian sejumlah 100 orang pegawai BPR di Kota Denpasar. Ringkasan mengenai karakteristik responden dapat dilihat pada Tabel 2 berikut:

Tabel 2.

Karakteristik Pegawai BPR di Kota Denpasar

\begin{tabular}{ccccc}
\hline No & Karakteristik & Klasifikasi & $\begin{array}{c}\text { Jumlah } \\
\text { Responden(orang) }\end{array}$ & $\begin{array}{c}\text { Persentase } \\
\text { Responden(\%) }\end{array}$ \\
1 & Usia & $21-30$ Tahun & 23 & 23 \\
& & $31-40$ Tahun & 40 & 40 \\
& & 40 Tahun & 37 & 61 \\
3 & Jenis & Laki-laki & 61 & 39 \\
& Kelamin & Perempuan & 39 & 6 \\
& Jenjang & SMA & 6 & 28 \\
& Pendidikan & Diploma & 28 & 52 \\
& Terakhir & S1 & 52 & 14 \\
& & S2 & 14 & 32 \\
4 & Lama Kerja & $5-10$ tahun & 32 & 51 \\
& & 10 tahun & 51 & 17 \\
\hline
\end{tabular}

Sumber :Data diolah, 2018

Tabel 2 menunjukkan lebih banyak pegawai laki-laki dibandingkan perempuan yang bekerja pada BPR di Kota Denpasar. Dilihat dari segi usia, 
menunjukkan bahwa pegawai yang bekerja pada BPR di Kota Denpasar yang terlibat secara langsung dalam menggunakan sistem informasi akuntansi untuk penyusunan laporan keuangan mayoritas adalah yang berusia 31-40 tahun. Kriteria responden berdasarkan tingkat pendidikan memberikan gambaran bahwa pegawai BPR di Kota Denpasar yang terlibat secara langsung dalam menggunakan sistem informasi akuntansi untuk penyusunan laporan keuangan paling dominan adalah lulusan Sarjana yang dianggap sudah mampu serta memadai untuk menjadi pegawai BPR yang memiliki kompetensi untuk mencapai tujuan organisasi.

Pengelompokkan responden berdasarkan masa kerjamenunjukkan bahwa sebagian besar pegawai BPR di Kota Denpasar yang terlibat secara langsung dalam menggunakan sistem informasi akuntansi untuk penyusunan laporan keuangan memiliki masa kerja 5 sampai 10 tahun.

Hasil uji validitas dan reliabilitas menunjukkan bahwa seluruh instrumen penelitian yang digunakan untuk mengukur variabelkepercayaan, perceived usefulness dan minat beli memiliki nilai koefisien korelasi dengan skor total seluruh item pernyataan lebih besar dari 0,30 dan memiliki koefisien Cronbach's Alpha lebih dari 0,60. Menunjukkan bahwa butir-butir pernyataan dalam instrument penelitian tersebut valid dan reliabel, sehingga layak digunakan sebagai instrument penelitian. 
Tabel 3.

Hasil Uji Validitas dan Reliabilitas Instrumen Penelitian

\begin{tabular}{|c|c|c|c|c|c|}
\hline Variabel & Indikator & $\begin{array}{l}\text { Koefisien } \\
\text { Korelasi }\end{array}$ & $\begin{array}{l}\text { Sig. }(2- \\
\text { tailed })\end{array}$ & $\begin{array}{c}\text { Cronbach's } \\
\text { Alpha }\end{array}$ & Keterangan \\
\hline \multirow{3}{*}{$\begin{array}{c}\text { Performance } \\
\text { expectancy }\left(\mathrm{X}_{1}\right)\end{array}$} & $\mathrm{X}_{1.1}$ & 0,744 & 0,000 & \multirow{4}{*}{0,810} & \multirow{4}{*}{$\begin{array}{l}\text { Valid dan } \\
\text { Reliabel }\end{array}$} \\
\hline & $\mathrm{X}_{1.2}$ & 0,823 & 0,000 & & \\
\hline & $\mathrm{X}_{1.3}$ & 0,793 & 0,000 & & \\
\hline \multirow{6}{*}{ Effort expectancy $\left(\mathrm{X}_{2}\right)$} & $\mathrm{X}_{1.4}$ & 0,780 & 0,000 & & \\
\hline & $\mathrm{X}_{1.5}$ & 0,683 & 0,000 & \multirow{4}{*}{0,752} & \multirow{4}{*}{$\begin{array}{l}\text { Valid dan } \\
\text { Reliabel }\end{array}$} \\
\hline & $\mathrm{X}_{2.1}$ & 0,688 & 0,000 & & \\
\hline & $\mathrm{X}_{2.2}$ & 0,709 & 0,000 & & \\
\hline & $\mathrm{X}_{2.3}$ & 0,533 & 0,000 & & \\
\hline & $\mathrm{X}_{2.4}$ & 0,790 & 0,000 & \multirow{4}{*}{0,809} & \multirow{4}{*}{$\begin{array}{l}\text { Valid dan } \\
\text { Reliabel }\end{array}$} \\
\hline \multirow{2}{*}{$\begin{array}{l}\text { Social influence } \\
\text { condition }\left(\mathrm{X}_{3}\right)\end{array}$} & $\mathrm{X}_{3.1}$ & 0,721 & 0,000 & & \\
\hline & $\mathrm{X}_{3.2}$ & 0,796 & 0,000 & & \\
\hline \multirow{5}{*}{$\begin{array}{l}\text { Facilitation condition } \\
\qquad\left(\mathrm{X}_{4}\right)\end{array}$} & $\mathrm{X}_{3.3}$ & 0,806 & 0,000 & & \\
\hline & $\mathrm{X}_{3.4}$ & 0,762 & 0,000 & \multirow{4}{*}{0,816} & \multirow{4}{*}{$\begin{array}{l}\text { Valid dan } \\
\text { Reliabel }\end{array}$} \\
\hline & $\mathrm{X}_{4.1}$ & 0,820 & 0,000 & & \\
\hline & $\mathrm{X}_{4.2}$ & 0,808 & 0,000 & & \\
\hline & $\mathrm{X}_{4.3}$ & 0,820 & 0,000 & & \\
\hline \multirow{5}{*}{ Kualitas sistem $\left(\mathrm{X}_{5}\right)$} & $\mathrm{X}_{5.1}$ & 0,396 & 0,000 & \multirow{5}{*}{0,646} & \multirow{5}{*}{$\begin{array}{l}\text { Valid dan } \\
\text { Reliabel }\end{array}$} \\
\hline & $\mathrm{X}_{5.2}$ & 0,480 & 0,000 & & \\
\hline & $\mathrm{X}_{5.3}$ & 0,532 & 0,000 & & \\
\hline & $\mathrm{X}_{5.4}$ & 0,535 & 0,000 & & \\
\hline & $\mathrm{X}_{5.5}$ & 0,538 & 0,000 & & \\
\hline \multirow{6}{*}{ Kualitas informasi $\left(\mathrm{X}_{6}\right)$} & $\mathrm{X}_{6.1}$ & 0,729 & 0,000 & \multirow{6}{*}{0,775} & \multirow{6}{*}{$\begin{array}{l}\text { Valid dan } \\
\text { Reliabel }\end{array}$} \\
\hline & $\mathrm{X}_{6.2}$ & 0,709 & 0,000 & & \\
\hline & $\mathrm{X}_{6.3}$ & 0,654 & 0,000 & & \\
\hline & $\mathrm{X}_{6.4}$ & 0,669 & 0,000 & & \\
\hline & $\mathrm{X}_{6.5}$ & 0,753 & 0,000 & & \\
\hline & $\mathrm{X}_{6.6}$ & 0,686 & 0,000 & & \\
\hline \multirow{5}{*}{ Kinerja individu(Y) } & $\mathrm{Y}_{1}$ & 0,545 & 0,000 & \multirow{5}{*}{0,761} & \multirow{5}{*}{$\begin{array}{l}\text { Valid dan } \\
\text { Reliabel }\end{array}$} \\
\hline & $\mathrm{Y}_{2}$ & 0,660 & 0,000 & & \\
\hline & $\mathrm{Y}_{3}$ & 0,703 & 0,000 & & \\
\hline & $\mathrm{Y}_{4}$ & 0,697 & 0,000 & & \\
\hline & $Y_{5}$ & 0,682 & 0,000 & & \\
\hline
\end{tabular}

Sumber : Data diolah, 2018

Statistik deskriptif bertujuan untuk memberikan informasi mengenai karakteristik variabel - variabel penelitian yaitu jumlah amata nilai minimum, nilai maksimum, nilai mean, dan standar deviasi. Untuk mengukur nilai sentral dari distribusi data dapat dilakukan dengan pengukuran rata - rata (mean) 
sedangkan standar deviasi merpakan perbedaan nilai data yang diteliti dengan nilai rata - ratanya. Hasil statistik deskriptif dapat dilihat pada Tabel 4.

Tabel 4.

Hasil Uji Statistik Deskriptif

\begin{tabular}{|c|c|c|c|c|c|}
\hline \multicolumn{6}{|c|}{ Descriptive Statistics } \\
\hline & $\mathrm{N}$ & Minimum & Maximum & Mean & Std. Deviation \\
\hline $\mathrm{X} 1.1$ & 100 & 1.00 & 4.00 & 3.1200 & .74237 \\
\hline $\mathrm{X} 1.2$ & 100 & 1.00 & 4.00 & 3.0700 & .78180 \\
\hline $\mathrm{X} 1.3$ & 100 & 2.00 & 4.00 & 3.3100 & .67712 \\
\hline $\mathrm{X} 1.4$ & 100 & 2.00 & 4.00 & 3.2700 & .75015 \\
\hline Performance Expectancy & 100 & 8.00 & 16.00 & 12.7700 & 2.31750 \\
\hline $\mathrm{X} 2.1$ & 100 & 1.00 & 4.00 & 3.2500 & .65713 \\
\hline $\mathrm{X} 2.2$ & 100 & 2.00 & 4.00 & 3.2000 & .60302 \\
\hline $\mathrm{X} 2.3$ & 100 & 1.00 & 4.00 & 3.2000 & .65134 \\
\hline $\mathrm{X} 2.4$ & 100 & 1.00 & 4.00 & 3.1900 & .72048 \\
\hline Effort Expectancy & 100 & 8.00 & 16.00 & 12.8400 & 1.70986 \\
\hline X3.1 & 100 & 2.00 & 4.00 & 3.1400 & .73882 \\
\hline $\mathrm{X} 3.2$ & 100 & 1.00 & 4.00 & 3.1300 & .64597 \\
\hline X3.3 & 100 & 1.00 & 4.00 & 3.0600 & .74968 \\
\hline $\mathrm{X} 3.4$ & 100 & 2.00 & 4.00 & 3.2900 & .75605 \\
\hline Social Influence Condition & 100 & 8.00 & 16.00 & 12.6200 & 2.25532 \\
\hline $\mathrm{X} 4.1$ & 100 & 1.00 & 4.00 & 3.2400 & .75371 \\
\hline $\mathrm{X} 4.2$ & 100 & 1.00 & 4.00 & 3.1400 & .79162 \\
\hline $\mathrm{X} 4.3$ & 100 & 1.00 & 4.00 & 3.0400 & .80302 \\
\hline $\mathrm{X} 4.4$ & 100 & 1.00 & 4.00 & 3.0800 & .84900 \\
\hline Facilitation Condition & 100 & 5.00 & 16.00 & 12.5000 & 2.56826 \\
\hline X5.1 & 100 & 1.00 & 4.00 & 2.7000 & .84686 \\
\hline X5.2 & 100 & 1.00 & 4.00 & 3.1800 & .59255 \\
\hline X5.3 & 100 & 1.00 & 4.00 & 3.3100 & .63078 \\
\hline X5.4 & 100 & 1.00 & 4.00 & 3.3000 & .61134 \\
\hline X5.5 & 100 & 1.00 & 4.00 & 3.1000 & .67420 \\
\hline Kualitas Sistem & 100 & 11.00 & 19.00 & 15.5900 & 1.64590 \\
\hline X6.1 & 100 & 2.00 & 4.00 & 3.3000 & .74536 \\
\hline X6.2 & 100 & 2.00 & 4.00 & 3.2600 & .71943 \\
\hline X6.3 & 100 & 1.00 & 4.00 & 3.2900 & .70058 \\
\hline X6.4 & 100 & 1.00 & 4.00 & 3.3700 & 69129 \\
\hline X6.5 & 100 & 2.00 & 4.00 & 3.3300 & 62044 \\
\hline X6.6 & 100 & 1.00 & 4.00 & 3.2700 & .78951 \\
\hline Kualitas Informasi & 100 & 14.00 & 24.00 & 19.8200 & 2.98271 \\
\hline Y1 & 100 & 2.00 & 4.00 & 3.2700 & .60059 \\
\hline Y2 & 100 & 1.00 & 4.00 & 3.1900 & .59789 \\
\hline Y3 & 100 & 2.00 & 4.00 & 3.3700 & .61390 \\
\hline Y4 & 100 & 1.00 & 4.00 & 3.0400 & .75103 \\
\hline Y5 & 100 & 2.00 & 4.00 & 3.3700 & .61390 \\
\hline Kinerja Individu & 100 & 11.00 & 20.00 & 16.2400 & 2.08467 \\
\hline Valid N (listwise) & 100 & & & & \\
\hline
\end{tabular}

Berdasarkan hasil uji statistik deskriptif pada Tabel 4 dapat diketahui bahwa total sampel yang digunakan adalah 100 orang responden. Hasil statistik 
deskriptif dalam penelitian ini menunjukkan nilai standar deviasi seluruh variabel lebih rendah dibandingkan dengan nilai rata-rata, yang artinya sebaran data terkait dengan variabel yang diuji sudah merata.

Model regresi akan lebih tepat digunakan dan menghasilkan perhitungan yang lebih akurat, apabila beberapa asumsi berikut dapat terpenuhi. Hasil uji asumsi klasik dalam penelitian ini dapat dilihat pada Tabel 5.

Tabel 5.

Rangkuman Hasil Uji Asumsi Klasik

\begin{tabular}{|c|c|c|c|c|}
\hline \multirow{2}{*}{$\begin{array}{c}\text { Hasil Uji } \\
\text { Normalitas }\end{array}$} & \multirow[t]{2}{*}{ Variabel } & \multicolumn{2}{|c|}{ Hasil Uji } & \multirow{2}{*}{$\begin{array}{c}\text { Hasil Uji } \\
\text { Heteroskedastisitas } \\
\text { Signifikansi }\end{array}$} \\
\hline & & Tolerance & VIF & \\
\hline \multirow{6}{*}{0,650} & Performance expectancy & 0,472 & 2,120 & 0,472 \\
\hline & Effort expectancy & 0,668 & 1,497 & 0,668 \\
\hline & Social influence condition & 0,376 & 2,661 & 0,376 \\
\hline & Facilitation condition & 0,481 & 2,081 & 0,481 \\
\hline & Kualitas sistem & 0,797 & 1,255 & 0,797 \\
\hline & Kualitas informasi & 0,525 & 1,905 & 0,525 \\
\hline
\end{tabular}

Sumber: Data diolah, 2018

Tabel 5 menunjukkan bahwa semua uji asumsi klasik sudah terpenuhi sehingga hasil analisis regresi layak untuk dibahas lebih lanjut.Perhitungan koefisien regresi linier berganda dilakukan dengan analisis regresi melalui software SPSS 18.0 for Windows, diperoleh hasil yang ditunjukan pada Tabel 6 .

Nilai koefisien regresi masing-masing variabel bebas bernilai positif dengan nilai signifikansi uji t kurang dari 0,05. Hal ini menunjukkan bahwa semua variabel bebas memiliki pengaruh positif yang signifikan terhadap variabel terikat.Besarnya pengaruh variabel bebas terhadap variabel terikat yang ditunjukkan oleh nilai determinasi total (R Square) sebesar 0,675 mempunyai arti bahwa sebesar 67,5\% variasi kinerja individu dalam penggunaan Sistem Informasi Akuntansipada BPR di Kota Denpasar dipengaruhi oleh variasi performance 
expectancy, effort expectancy, social influence condition, facilitation condition, kualitas sistem dan kualitas informasi, sedangkan sisanya sebesar 32,5\% djelaskan oleh faktor lain yang tidak dimasukkan ke dalam model.

Tabel 6.

Hasil Analisis Regresi Linier Berganda

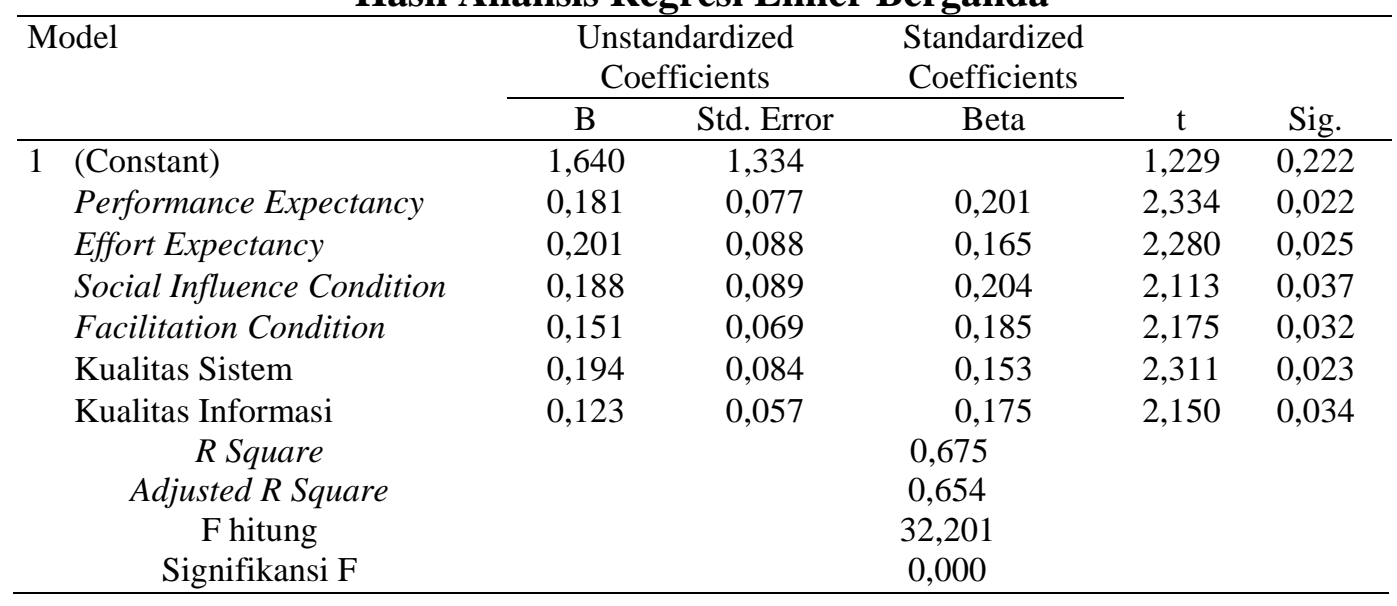

Sumber : Data diolah, 2018

Hasil analisis regresi linier berganda seperti yang disajikan pada Tabel 6 , maka dapat dibuat persamaan regresi sebagai berikut:

$$
Y=1,640+0,181 X_{1}+0,201 X_{2}+0,188 X_{3}+0,151 X_{4}+0,194 X_{5}+0,123 X_{6}+\varepsilon
$$

Tabel 6 menunjukkan nilai $F_{\text {hitung }}$ sebesar 32,201 dengan signifkansi sebesar $0,000<0,05$, maka dapat disimpulkan bahwa pada kelompok yang diuji memiliki perbedaan yang nyata (signifikan). Hasil ini mempunyai arti bahwa ada pengaruh signifikan antara performance expectancy, effort expectancy, social influence condition, facilitation condition, kualitas sistem dan kualitas informasisecara simultan terhadap kinerja individu dalam penggunaan Sistem Informasi Akuntansi pada BPR di Kota Denpasar.

Berdasarkan hasil analisis pengaruh performance expectancy terhadap kinerja individudiperoleh nilai signifikasi sebesar 0,022 dengan nilai koefisien 
beta 0,181 . Nilai Signifikansi $0,022<0,05$ mengindikasikan bahwa $\mathrm{H}_{0}$ ditolak dan $\mathrm{H}_{1}$ diterima. Hasil ini mempunyai arti bahwa performance expectancyberpengaruh positif dan signifikan terhadap kinerja individu dalam penggunaan Sistem Informasi Akuntansi pada BPR di Kota Denpasar.Semakin tinggi ekpektasi kinerja pegawai maka kinerja yang dihasilkan akan semakin meningkat. Begitu pula sebaliknya, semakin rendah ekpektasi kinerja seorang pegawai maka semakin rendah tingkat kinerja individu tersebut.

Penelitian ini konsisten dengan hasil penelitian yang dilakukan oleh Pertiwi dan Ariyanto (2017), menyatakan bahwa Seseorang yang merasa pekerjaannya dimudahkan dengan menggunakan suatu sistem akan memiliki minat untuk memanfaatkan sistem tersebut dan menggunakannya secara berkelanjutan. Sistem informasi mampu memberikan hal positif dalam penggunaannya ketika sistem informasi tersebut mempermudah seseorang dalam peningkatan kinerjanya. Hasil uji statistik deskriptif, penggunaan SIA di BPR akan mampu meningkatkan mutu layanan BPR mendapat nilai skor rata-rata yang paling tinggi. Seorang individu menggunakan SIA di BPR akan mampu meningkatkan mutu dan layanan, adanya sistem informasi akuntansi yang baik maka perusahaan dapat melakukan proses operasi maupun mengolah informasi dengan lebih efektif dan efisien karena adanya pengendalian yang mampu mengendalikan proses-proses tersebut sehingga dapat menghasilkan tujuan yang sesuai dengan yang diinginkan perusahaan.

Hasil analisis pengaruh effort expectancy terhadap kinerja individu diperoleh nilai signifikansi sebesar 0,025 dengan nilai koefisien beta 0,201. Nilai 
Signifikansi $0,025<0,05$ mengindikasikan bahwa $\mathrm{H}_{0}$ ditolak dan $\mathrm{H}_{2}$ diterima. Hasil ini mempunyai arti bahwa effort expectancyberpengaruh positif dan signifikan terhadap kinerja individu dalam penggunaan Sistem Informasi Akuntansi pada BPR di Kota Denpasar. Semakin tinggi effort expectancy seorang pegawai maka kinerja individu yang dihasilkan akan semakin bertambah. Begitu pula sebaliknya, semakin rendah effort expectancy seorang pegawai,maka semakin rendah tingkatkinerja individu tersebut.

Penelitian ini konsisten dengan hasil penelitian yang dilakukan oleh Mustaqim et al,(2018) yang menyatakan bahwa effort expetancy terbukti memiliki pengaruh positif dan signifikan terhadap kinerja individu.Hasil penelitian ini juga mendukung hasil penelitianSedana dan Wijaya (2012), yang memperoleh hasil bahwa effort expectancy berpengaruh signifikan terhadap kinerja individu.

Hasil uji statistik deskriptif, pegawai merasa SIA di BPR mudah digunakan mendapat nilai skor rata-rata yang paling tinggi. Seorang individu meyakini bahwa SIA itu mudah digunakan akan membantu dalam meningkatkan kinerjanya (memiliki ekspektasi kinerja yang tinggi), dan terdapat kemudahan pemakaian penggunaan teknologi informasi (ekspektasi usaha) tersebut, maka individu tersebut akan termotivasi untuk meningkatkan kinerjanya dengan memanfaatkan sistem teknologi informasi yang tersedia di perusahaan.

Hasil analisis pengaruh social influence condition terhadap kinerja individu diperoleh nilai signifikansi sebesar 0,037 dengan nilai koefisien beta 0,188. Nilai signifikansi $0,037<0,05$ mengindikasikan bahwa $\mathrm{H}_{0}$ ditolak dan $\mathrm{H}_{3}$ diterima. Hasil ini mempunyai arti bahwa social influence condition berpengaruh 
positif dan signifikan kinerja individu dalam penggunaan Sistem Informasi Akuntansi pada BPR di Kota Denpasar. Semakin tinggi tingkat social influence condition maka akan berpengaruh pada semakin meningkatnya kinerja individu dalam penggunaan Sistem Informasi Akuntansi pada BPR di Kota Denpasar. Begitu pula sebaliknya, semakin rendah tingkat social influence condition maka akan berpengaruh pada semakin berkurangnya kinerja individudalam penggunaan Sistem Informasi Akuntansi pada BPR di Kota Denpasar.

Penelitian ini konsisten dengan hasil penelitian yang dilakukan oleh Wicaksono et al, (2017) yang memperoleh hasil bahwa faktor sosial berpengaruh positif dan signifikan terhadap kinerja individu. Hasil penelitian ini mendukung temuan penelitian Davis dan Venkatesh (1996), Pertiwi dan Ariyanto (2017), serta Sari dan Maria (2009), menyatakan bahwa faktor sosial memiliki pengaruh yang positif pada kinerja individu.

Uji statistik deskriptif, kebijakan pimpinan BPR mendukung saya menggunakan SIA mendapat nilai skor rata-rata yang paling tinggi. Seorang individu mendapat dukungan sosial yang tinggi dari rekan kerja maupun atasannya bahwa dia harus menggunakan sistem baru dalam pekerjaannya, maka individu tersebut akan termotivasi untuk meningkatkan kinerjanya dengan memanfaatkan sistem teknologi informasi yang tersedia di perusahaan.

Hasil analisis pengaruh facilitation condition terhadap kinerja individu diperoleh nilai signifikansi sebesar 0,032 dengan nilai koefisien beta 0,151 . Nilai signifikansi 0,032<0,05 mengindikasikan bahwa $\mathrm{H}_{0}$ ditolak dan $\mathrm{H}_{4}$ diterima. Hasil ini mempunyai arti bahwa facilitation condition berpengaruh positif dan 
signifikan terhadap Kinerja individu dalam penggunaan Sistem Informasi Akuntansi pada BPR di Kota Denpasar. Semakin baik Facilitation condition yang diberikan maka kinerja individu juga akan semakin meningkat.Ini berarti bahwa apabila kondisi fasilitas pekerjaan pada BPR di Kota Denpasar semakin membaik maka akan mampu meningkatkan kinerja individu dalam penggunaan Sistem Informasi Akuntansi pada BPR tersebut. Begitu pula sebaliknya, semakin buruk facilitation condition yang diberikan maka kinerja individu juga akan semakin menurun.

Hasil penelitian yaitu kondisi fasilitasi secara signifikan mempengaruhi kinerja individu. Hasil penelitian ini mendukung temuan Pertiwi dan Ariyanto (2017), yang mendapatkan hasil bahwa kondisi yang memfasilitas berpengaruh positif terhadap kinerja individu dalam menggunakan sistem teknologi informasi.

Hasil uji statistik deskriptif, saya memiliki penggetahuan yang cukup untuk menggunakan SIA mendapat nilai skor rata-rata yang paling tinggi. Seorang individu memiliki pengetahuan yang cukup atau lebih untuk menggunakan SIA akan memudahkan menjalankan sistem baru dalam pekerjaannya dan juga didukung oleh tersedianya fasilitas penggunaan teknologi informasi dari organisasi, maka individu tersebut akan termotivasi untuk meningkatkan kinerjanya dengan memanfaatkan sistem teknologi informasi yang tersedia di perusahaan.

Hasil analisis pengaruh kualitas sistem terhadap kinerja individu diperoleh nilai signifikansi sebesar 0,023 dengan nilai koefisien beta 0,194. Nilai signifikansi $0,023<0,05$ mengindikasikan bahwa $\mathrm{H}_{0}$ ditolak dan $\mathrm{H}_{5}$ diterima. 
Hasil ini mempunyai arti bahwa kualitas sistem berpengaruh positif dan signifikan terhadap kinerja individu dalam penggunaan Sistem Informasi Akuntansi pada BPR di Kota Denpasar. Semakin baik kualitas sistem yang di miliki oleh BPR, maka kinerja individu yang dihasilkan juga akan semakin baik. Ini berarti bahwa apabila kualitas sistem yang diterapkan BPR semakin mempermudah pekerjaan pegawai maka akan cenderung meningkatkan kinerja individu dalam penggunaan Sistem Informasi Akuntansi pada BPR di Kota Denpasar. Begitu pula sebaliknya, semakin buruk kualitas sistem yang dimiliki oleh BPR, maka kinerja individu juga akan semakin rendah.

Penelitian ini konsisten dengan hasil penelitian yang dilakukan oleh Jati dan Lakstio (2012), yang mendapatkan hasil yaitu kualitas sistem informasi dapat mempengaruhi kinerja individu pengguna sistem informasi. Hasil uji statistik deskriptif, kesalahan yang terjadi mudah diidentifikasi dan dikoreksi mendapat nilai skor rata-rata yang paling tinggi.Seorang individu dalam menjalankan tugasnya melakukan kesalahan akan lebih mudah mengkoreksi kesalahan tersebut dengan sistem yang baik, semakin baik kualitas sistem yang dimiliki pada perusahaan, maka kinerja individu akan semakin meningkat.

Hasil analisis pengaruh kualitas informasi terhadap kinerja individu diperoleh nilai signifikansi sebesar 0,034 dengan nilai koefisien beta 0,123. Nilai signifikansi 0,034<0,05 mengindikasikan bahwa $\mathrm{H}_{0}$ ditolak dan $\mathrm{H}_{6}$ diterima. Hasil ini mempunyai arti bahwa kualitas informasi berpengaruh positif dan signifikan terhadap kinerja individu dalam penggunaan Sistem Informasi Akuntansi pada BPR di Kota Denpasar. Semakin baik kualitas informasi yang dimiliki oleh BPR, 
maka kinerja individu yang dihasilkan juga akan semakin baik. Ini berarti bahwa apabila BPR mampu menyedian informasi berkualitas yang berguna untuk mempermudah pekerjaa pegawai, maka akan cenderung meningkatkan kinerja individu dalam penggunaan Sistem Informasi Akuntansi pada BPR di Kota Denpasar. Begitu pula sebaliknya, semakin burukkualitas informasi yang dimiliki oleh BPR, maka kinerja individu juga akan semakin rendah.

Penelitian ini konsisten dengan hasil penelitian yang dilakukan oleh Ajzen (2005) yang mendapatkan hasil yaitu kualitas informasi dapat mempengaruhi kinerja individu pengguna sistem informasi. Hasil penelitian ini mendukung temuan Harash at al, (2014) yang memperoleh hasil bahwa kualitas informasi berpengaruh positif terhadap kinerja individu dalam penggunaan sistem informasi. Berdasarkan hasil uji statistik deskriptif, informasi yang dihasilkan oleh SIA di BPR relevan mendapat nilai skor rata-rata yang paling tinggi. Semakin baik kualitas sistem yang dimiliki dan semakin relevan kualitas informasi yang dihasilkan oleh perusahaan, maka kinerja individu akan semakin meningkat.

\section{SIMPULAN}

Simpulan yang dapat diberikan berdasarkan hasil analisis data dan pembahasan yang telah diuraikan yaitu ekspektasi kinerja (performance expectancy), ekspektasi usaha (effort expectancy), faktor sosial (social influence), kondisi yang memfasilitasi (facilitating conditions), kualitas sistem dan kualitas informasi berpengaruh positif dan signifikan terhadap persepsi kinerja individu pada sistem informasi akuntansi BPR di Kota Denpasar. 


\section{REFERENSI}

Ajzen, I. (2005). Attitudes, Personality and Behaviour. In Mapping Social Psychology.

ALsarayreh, M. N., Jawabreh, O. A. A., Jaradat, M. M. F., \& ALamro, S. A. (2011). Technological impacts on effectiveness of accounting information systems (AIS) applied by Aqaba tourist hotels. European Journal of Scientific Research, 59(3), 361-369. Retrieved from

Bekti, B. C. (2014). Model Penerimaan Supervisi Akademik Melalui E-Training Berbasis Media Sosial pada Guru SMK. Educational Management.

Bendi, R. K. J., \& Sri Andayani. (2013). Analisis Perilaku Penggunaan Sistem Informasi Menggunakan Model UTAUT. Seminar Nasional Teknologi Informasi \& Komunikasi Terapan 2013 (Semantik 2013).

Chau, P. Y. K., \& Hu, P. J. (2002). Examining a model of information technology acceptance by individual professionals: An exploratory study. Journal of Management Information Systems, 18(4), 191-229.

Davis, F. D., \& Venkatesh, V. (1996). A critical assessment of potential measurement biases in the technology acceptance model: Three experiments. International Journal of Human-Computer Studies, 45(1), 19-45.

DeLone, W., \& McLean, E. (1992). Information System Success: The Quest for the Dependent Variable. Information Systems Research, 3(1), 60-65. https://doi.org/10.1287/isre.3.1.60

Dewi Mas Yogi Pertiwi, N. W., \& Ariyanto, D. (2017). Penerapan Model UTAUT 2 Untuk Menjelaskan Minat dan Perilaku Penggunaan Mobile Banking di Kota Denpasar. E-Jurnal Akuntansi.

Handayani, R. (2003). Analisis Faktor-Faktor yang Mempengaruhi Minat Pemanfaatan Sistem Informasi dan Penggunaan Sistem Informasi ( Studi Empiris Pada Perusahaan Manufaktur di Bursa Efek Jakarta ). Jurnal Akuntansi Dan Keuangan.

Harash, E., Al-Timimi, S., \& Radhi, A. H. (2014). The Influence of Accounting Information Systems (AIS) on Performance of Small and Medium Enterprises (SMEs) in Iraq. Journal of Business and Management, 3(4), 48-57.

Jap, E., Elizabeth Vallery, M., \& Smith, L. M. (2006). Information Technology and Systems Research Published in Major Accounting Academic and Professional Journal. Journal of Emerging Technologies in Accounting, 3, 117-128. Retrieved from

Jati, N. J., \& Lakstio, H. (2012). Analisis Faktor-Faktor Yang Mempengaruhi Minat Pemanfaatan Dan Penggunaan Sistem E-Ticket (Studi Empiris pada Biro Perjalanan di Kota Semarang). Jurusan Akuntansi Fakultas Ekonomika Dan Bisnis Universitas Diponegoro.

Krismadinata, K., Arnovia, Y., Syahril, S., \& Yahfizham, Y. (2018). Kontribusi Ekspektasi Kinerja, Usaha, Faktor Sosial dan Fasilitas Terhadap Sikap Operator Sistem Informasi. Jurnal Nasional Teknologi Dan Sistem Informasi. 
Marlinawati, N. M. A. dan I. G. N. A. S. (2013). Pengaruh Penggunaan Teknologi Informasi, Efektivitas Sistem Informasi Akuntansi, Kepercayaan Atas Sistem Informasi Akuntansi, Dan Kesesuaian Tugas Pada Kinerja Karyawan Lembaga Pengkreditan Desa Di Kabupaten Badung. E-Jurnal Akuntansi Universitas Udayana, 2(2), 388-401.

Meiranto, W. (2018). Kajian Online Sistem Informasi BRI (BRINETS): Pendekatan Technology Acceptance Model (TAM). Jurnal Akuntansi Multiparadigma. https://doi.org/10.18202/jamal.2011.04.7112

Mustaqim, R., Kusyanti, A., \& Aryadita, H. (2018). Analisis Faktor-Faktor yang Memengaruhi Niat Penggunaan E-Commerce XYZ Menggunakan Model UTAUT (Unified Theory Acceptance and Use Of Technology). Jurnal Pengembangan Teknologi Informasi Dan Ilmu Komputer.

Radityo, D., \& Zulaikha. (2007). Pengujian Model DeLone and McLean Dalam Pengembangan Sistem Informasi Manajemen ( Kajian Sebuah Kasus ). Simposium Nasional Akuntansi X, 1-25.

Rahmawati, D. (2008). Analisis Faktor-Faktor Yang Berpengaruh Terhadap Pemanfaatan Teknologi Informasi. Jurnal Ekonomi \& Pendidikan, Volume 5 N(1996), 107-118. Retrieved from http://journal.uny.ac.id/index.php/jep/article/viewFile/606/463

Risiyanto, 2014. (2014). Pengaruh Kualitas Informasi, Kualitas Sistem, Dan Kualitas Layanan Terhadap Kepuasan Pengguna Pada Sistem Informasi Klinik. Yogyakarta, Unversitas Negeri Yogyakarta.

Sari, R., \& Maria, M. (2009). Pengaruh Efektivitas Penggunaan dan Kepercayaan Terhadap Teknologi Sistem Informasi Akuntansi Terhadap Kinerja Individual pada Pasar Swalayan di Kota Denpasar. Jurnal Ilmiah Akuntansi Dan Bisnis, 4(1).

Sedana, I. G. N., \& Wijaya, S. W. (2012). Penerapan Model Utaut Untuk Memahami Penerimaan Dan Penggunaan Learning Management System Studi Kasus: Experential E-Learning Of Sanata Dharma University. Jurnal Sistem Informasi.

Wicaksono, A. P., Urumsah, D., \& Nugroho, G. (2017). Kinerja Individu Sebagai Dampak Penerimaan Teknologi: Pendekatan Model UTAUT. Jurnal Ilmiah Akuntansi. 